\title{
NECROLYTIC MIGRATORY ERYTHEMA ASSOCIATED WITH GLUCAGONOMA SYNDROME: A CASE REPORT
}

Cassio C. Dal Coleto, Ana Paula F. de Mello, Jaime Piquero-Casals, Fábio R. Lima, Maria Aparecida Constantino Vilela, Cyro Festa-Neto and José Antonio Sanches Jr.

RHCFAP/3059

DAL COLETO CC et al. - Necrolytic migratory erythema associated with glucagonoma syndrome: a case report. Rev. Hosp. Clín. Fac. Med. S. Paulo 56(6):183-188, 2001.

Necrolytic migratory erythema is a rare skin condition that consists of migrating areas of erythema with blisters that heal with hyperpigmentation. It usually occurs in patients with an alpha islet cell tumor of the pancreas—or glucagonoma-and when associated with glucose intolerance, anemia, hyperglucagonemia, and weight loss defines the glucagonoma syndrome.

We describe a 52-year-old female patient with necrolytic migratory erythema associated with glucagonoma syndrome who had metastatic disease at presentation and passed away one week after her admission. The autopsy showed a tumor in the body of the pancreas, which was diagnosed as a neuroendocrine tumor and confirmed by immunohistochemistry.

The diagnosis of necrolytic migratory erythema is a matter of great importance, since it might be an auxiliary tool for the early detection of glucagonoma.

DESCRIPTORS: Necrolytic migratory erythema. Glucagonoma syndrome. Glucagonoma.

Necrolytic migratory erythema (NME) is a rare skin condition characteristically presented as an irregular annular eruption with a serpiginous advancing border. Bullae may be seen at the centre of the lesions that subsequently erode and become crusted. The lesions occur most commonly on the perineum, distal extremities, lower abdomen, and face ${ }^{1-4}$.

NME usually appears as a paraneoplastic process in patients with alpha cell tumor of the pancreas, i.e., glucagonoma. Glucagonoma, in association with hyperglucagonemia, glucose intolerance, anemia, and weight loss, defines the glucagonoma syndrome $^{3,4}$.

Less often, NME may have no correlation with glucagonoma and be re- lated to celiac disease, malabsorption, chronic pancreatitis, infection and hepatic cirrhosis, or extrapancreatic glucagon-secreting tumor ( renal, duodenal, or pulmonary $)^{5-12}$. We describe a woman with NME associated with glucagonoma syndrome.

\section{CASE REPORT}

A 52-year-old white woman with an 8-month history of pruritic and burning skin eruption that rapidly progressed to involve the entire body was referred for

From the Department of Dermatology, Hospital das Clínicas, Faculty of Medicine, University of São Paulo. evaluation. The patient presented marked fatigue, anorexia, weakness, confusion, and a 20-pound weight loss over the previous 8 months.

She was treated with topical and systemic steroids (prednisone $20 \mathrm{mg}$ / day) for 2 months without clinical improvement. There was no history of alcohol intake or diabetes mellitus.

Examination revealed a cachectic woman with symmetrical erythematous, scaling and crusted annular plaques that were particularly prominent around perineum (Fig. 1). The lesions appeared as urticarial papules and small vesicles on the trunk. Symmetric erythema, blisters, and edema were observed on the legs and feet. Superficial erosions were present in the intertriginous areas. Glossitis and angu- 
lar stomatitis were also noted. The clinical differential diagnosis included zinc deficiency, pellagra, pemphigus vulgaris, and NME.

Examination of biopsy specimens showed an intraepidermal cleft, presence of vacuolated pale epidermal cells with pyknotic nuclei, and neutrophils in the upper epidermis (Fig. 2)-all changes consistent with NME.

A computed tomography scan of the abdomen revealed a $3-\mathrm{cm}$ pancre-

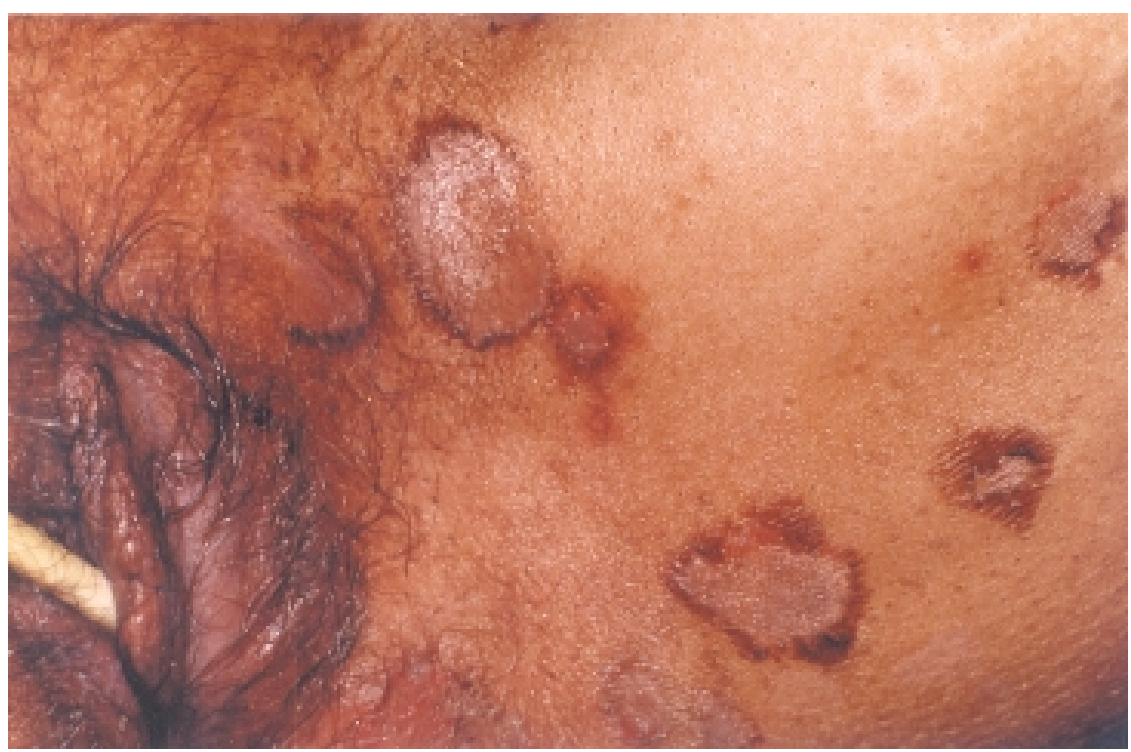

Fig. 1 - Scaling annular lesions around perineum.

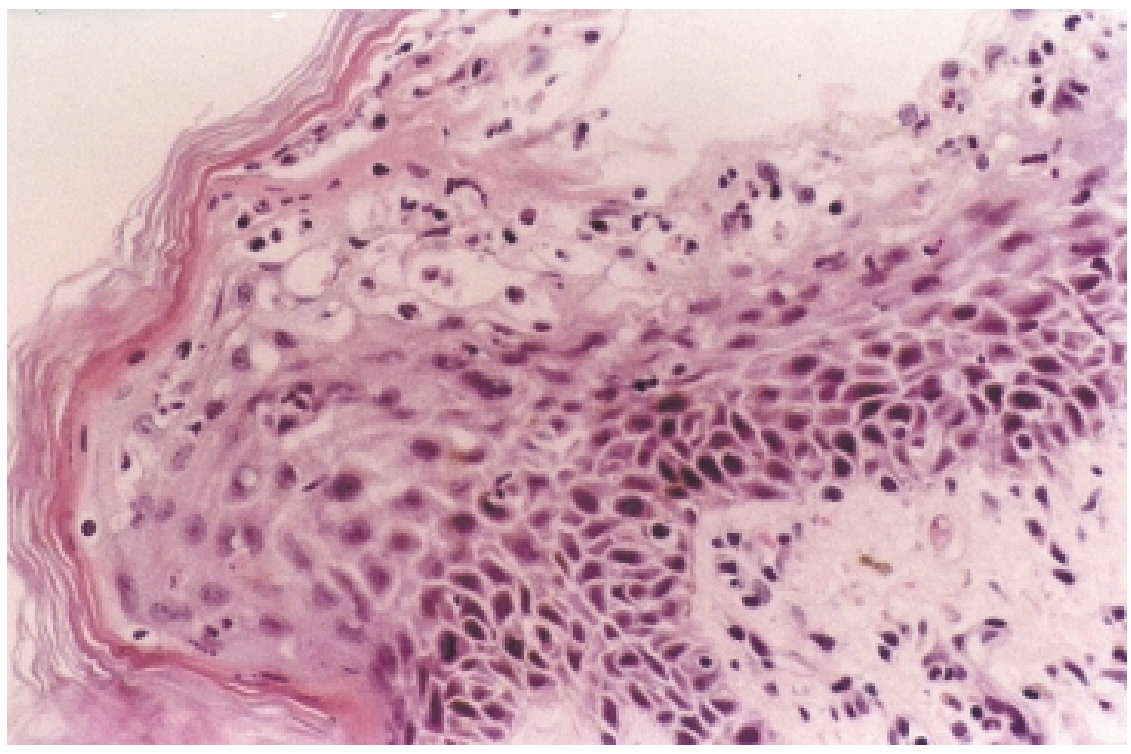

Fig. 2 - Biopsy specimen shows an intraepidermal cleft, vacuolated pale keratinocytes with pyknotic nuclei and neutrophils (HE 400X).

atic mass (Fig. 3) and multiple metastatic nodules in both lobes of the liver.

The serum glucagon level was markedly increased to $4517.1 \mathrm{pg} / \mathrm{mL}$ (normal 50 to $150 \mathrm{pg} / \mathrm{mL}$ ). Glycemia was increased to $204 \mathrm{mg} / 100 \mathrm{~mL}$ (normal 70 to $100 \mathrm{mg} / \mathrm{mL}$ ), hematocrit value was 22.1 (normal 35-45), and all serum amino acid levels were decreased. The serum zinc level was within normal limits. With the support of these findings, the diagnosis of small, relatively uniform cuboidal cells with centrally located nuclei and finely granular acidophilic cytoplasm, resulting in defined nests, separated by highly vascularized stroma (solid pattern) (Fig. 4). There was no evidence of glandular or trabecular differentiation. Mitotic figures were scarce. Immunohistochemical staining for chromogranin was strongly positive, while synaptophysin, insulin, glucagon, and somatostatin were negative.

\section{DISCUSSION}

Becker et al. ${ }^{13}$ described in 1942 a "diffuse progressive epidermal necrotic rash" associated with pancreatic neoplasm. In 1966, McGravan et al. ${ }^{14}$ reported hyperglucagonemia in a patient with an eczematoid, erythematous rash, mild diabetes mellitus, anemia, and a glucagon-secreting alpha cell tumor of the pancreas.

Mallinson et al. ${ }^{2}$ in 1974 defined the glucagonoma syndrome as presented in 9 patients with diabetes mellitus, anemia, weight loss, a distinctive rash referred as "necrolytic migratory erythema" (NME), and tumor of the islet cells of the pancreas. Glossitis, stomatitis, cheilitis, diffuse alopecia, diarrhea, hypoaminoacidemia, increased incidence of thromboembolism, and psychiatric disturbances complete the glucagonoma syndrome ${ }^{15}$.

Our patient had this rare and com- 


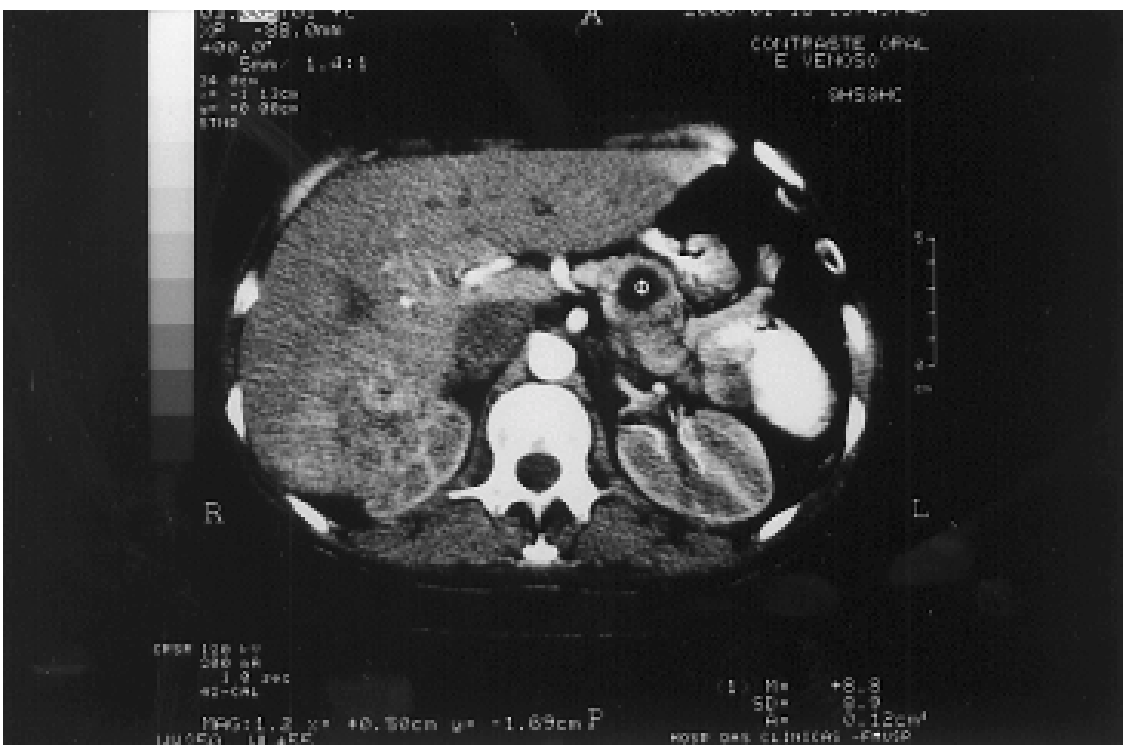

Fig. 3 - Pancreatic mass and metastatic nodules in the liver in computed tomography scan.

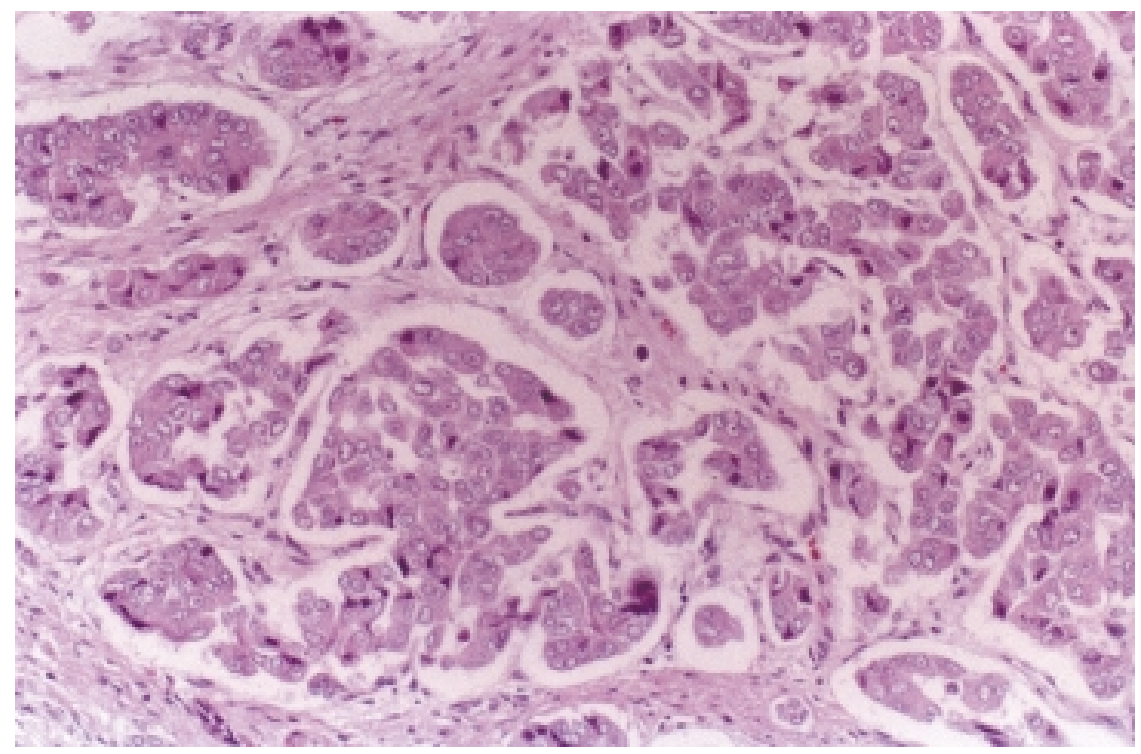

Fig. 4 - Pancreatic neuroendocrine neoplasm with a solid microscopic pattern (HE 100X).

plete syndrome, with metastatic disease at presentation, similar to what is reported in literature ${ }^{16}$.

Immunocytochemical findings show that glucagonoma has two distinct types: One associated with the glucagonoma syndrome, presented as a solitary and large tumor, with a solid microscopic pattern, low or lack of immunoreactivity for glucagon and high incidence of malignancy (60\% of patients); the other one, not associated with glucagonoma syndrome, has tumors that are often multiple and small, have a gyriform microscopic pattern of growth, are strongly immunoreactive for glucagon, and are always benign ${ }^{17-20}$.

The macroscopic and microscopic patterns of our patient's tumor were those of a neuroendocrine neoplasm of pancreatic islet cells. The positive immunohistochemistry for chromogranin confirmed this diagnosis. The negative immunohistochemistry for glucagon does not exclude the possibility of glucagonoma, since the majority of glucagonoma cases associated with this syndrome present low levels or lack immunohistochemical reactivity to glucagon.

There are many theories about the pathogenesis of NME. The effects on the skin of the glucagonoma syndrome that result in NME may be due directly to glucagon itself or to other factors.

The increased level of glucagon as a direct cause of NME is supported by some evidence: the demonstration in vitro that an increased level of glucagon yields greater amounts of epidermal arachidonic acid, which causes the inflammatory changes in the skin ${ }^{21}$; the cure of NME after surgical removal of the tumor, with consequent normalization of serum glucagon levels ${ }^{22-25}$; and the remission of the rash after therapy with somatostatin analogue (octreotide), which is a potent inhibitor of glucagon release $\mathrm{e}^{26,27}$.

However, other evidence fails to link NME with hyperglucagonemia, e.g., the report that only $52 \%$ of patients with non-glucagonoma-associated NME had an increased glucagon level ${ }^{12}$

Other theories that could explain the genesis of NME are based on the secondary effects of glucagon. Glucagon stimulates glycogenolysis, gluconeogenesis, ketogenesis, and consequently a systemic catabolic state ${ }^{28}$. The hypoaminoacidemia secondary to increased gluconeogenesis is suggested by some reports as a cause of $\mathrm{NME}^{29,30}$. However, several patients cleared the cutaneous lesions after amino acid infusions $^{29}$, and some patients with necrolytic migratory erythema had a normal amino acid level ${ }^{7,31}$, or did not improve after the supplementation ${ }^{22}$.

Delaney and Uff ${ }^{32}$ controlled NME using omega-3 triglycerides in a patient with a surgically unresectable glucagonoma. Also, improvement of the 
rash has been observed after zinc supplementation in patients who have a low ${ }^{8,33}$ or normal serum zinc level ${ }^{9,34}$.

The clinical and histologic similarities between NME, hereditary acrodermatitis, enteropathica secondary to zinc deficiency, pellagra, and fatty acid deficiency have been noted ${ }^{35-36}$. The re- semblance may be explained by this catabolic state.

Unfortunately, in the present case, the diagnosis was confirmed at a late stage of the disease, and the ideal treatment was not instituted. This case illustrates the importance of early recognition of NME, with its distinctive clinical and histopathologic features, as well as signs and symptoms that compose the glucagonoma syndrome.

These data suggest that the cause for the NME associated with glucagonoma is multifactorial, and it is likely that the postulated theories are not mutually exclusive.
DAL COLETO CC e col. - Eritema Necrolítico Migratório associado à Síndrome Glucagonoma: descrição de um caso. Rev. Hosp. Clín. Fac. Med. S. Paulo 55(6):183-188, 2001.

$\mathrm{O}$ eritema necrolítico migratório é uma rara condição cutânea que se apresenta como lesões eritematosas, migratórias, com vesículas e bolhas na superfície, evoluindo para cura com hiperpigmentação. É freqüentemente obser- vado em doentes com tumor de células alfa do pâncreas, ou glucagonoma, e quando associado com intolerância a glicose, anemia, hiperglucagonemia, e perda de peso definem a síndrome do glucagonoma.

É descrito o caso de uma paciente do sexo feminino, 52 anos, branca, com eritema necrolítico migratório associado à síndrome do glucagonoma com doença metastática na apresentação, vindo a falecer uma semana após sua admissão. A autópsia mostrou um tumor no corpo do pâncreas diagnosticado como tumor neuroendócrino e confirmado pela imuno-histoquímica. O reconhecimento do eritema necrolítico migratório é de grande importância para a possibilidade de diagnóstico precoce do glucagonoma.

DESCRITORES: Eritema necrolítico migratório. Síndrome glucagonoma. Glucagonoma. 


\section{REFERENCES}

1. SWEET RD - A dermatosis specifically associated with tumours of pancreatic alpha cells. Br J Dermatol 1974;90:301-308.

2. MALLINSON CN, BLOOM SR, WARIN AP et al. - A glucagonoma syndrome. Lancet 1974;2:1-5.

3. CHURCH RE \& CRANE WJ - A cutaneous syndrome associated with islet-cell carcinoma of the pancreas. Br J Dermatol 1967;79:284286.

4. WILKINSON DS - Necrolytic migratory erythema with pancreatic carcinoma. Proc R Soc Med 1971;64:1197-1198.

5. MARINKOVICH MP, BOTELLA R, DATLOFF J et al. - Necrolytic migratory erythema without glucagonoma in patients with liver disease. J Am Acad Dermatol 1995;32:605-609.

6. SIBRACK LA \& GOUTERMAN JH - Cutaneous manifestations of pancreatic diseases. Cutis 1978;125:460-462.

7. BLACFORD S, WRIGHT S \& ROBERTS DL - Necrolytic migratory erythema without glucagonoma: the role of dietary essencial fathy acids. Br J Dermatol 1991;125:460-462.

8. KELLY CP, JOHNSTON CF, NOLAN N et al. - Necrolytic migratory erythema with elevated plasma enteroglucagon in celiac disease. Gastroenterology 1989;96:1350-1353.

9. GOODENBERG DM, LAWLEY TJ, STROBER W et al. - Necrolytic migratory eruthema without glucagonoma. Report of two cases. Arch dermatol 1979;115:1429-1432.

10. TRUE L, CHARLES A, LEWI $\mathrm{H}$ et al. - A pseudoglucagonoma syndrome. Clin Res 1979;27:51A.

11. SCHWARTZ RA - Glucagonoma and pseudoglucagonoma syndromes.Review. Int J Dermatol 1997;36:81-99.

12. MULLANS EA \& COHEN PR - Iatrogenic necrolytic migratory erythema: A case report and review of nonglucagonoma-associated necrolytic migratory erythema. J Am Acad Dermatol 1998;38:866873.

13. BECKER SW, KAHN D \& ROTHMAN S - Cutaneous manifestations of internal malignant tumors. Arch Dermatol Syphilol 1942:45:1069-1080

14. MCGRAVAN MH, UNGER RH, RECANT L et al. - A glucagonsecreting alpha-cell carcinoma of the pancreas. $\mathbf{N}$ Engl J Med 1966;274:1408-1413.

15. WERMERS RA, VAHAB F, WYNE AG et al. - The glucagonoma syndrome. Medicine 1996;75:53-63.

16. MONTENEGRO-RODAS F \& SAMAAN NA - Glucagonoma tumors and syndrome. Curr Probl Cancer 1981;6:3-54.
17. ROSAI J - Pancreas and ampullary region. In: ROSAI J - Ackerman's Surgical Pathology. $8^{\text {th }}$ ed. St. Louis, Mosby, 1996. p. 990-999.

18. HAMID QA, BISHOP AE, SIKRI KL et al. - Immunecytochemical characterization of 10 pancreatic tumours, associated with the glucagonoma syndrome, using antibodies to separate regions of the proglucagon molecule and other neuroendocrine markers. Histopathology 1986:10:119-133.

19. NEVES JM, MARTINS JUNIOR EV, GABURRI AK et al. Glucagonoma: relato de caso e revisão de literatura. Arq Gastroenterol 1996;33:167-172.

20. KHEIR SM, OMURA EF, GRIZZLE WE et al. - Histologic variation in the skin lesions of the glucagonoma syndrome. Am J Surg Pathol 1986;10(7):445-453.

21. PETERSON LL, SHAW JC, ACOTT KM et al. - Glucagonoma syndrome: in vitro evidence that glucagon increases epidermal arachidonic acid. J Am Acad Dermatol 1984;2:468-473.

22. ABRAIRA C, DEBARTOLO M, KATZEN R et al. - Disappearance of glucagonoma rash after surgical resection, but not during dietary normalization of serum amino acids. Am J Clin Nutr 1984;39:351355 .

23. MONTENEGRO F, LAWRENCE GD, MACON W et al. - Metastatic glucagonoma. Improvement after surgical debulking. Am J Surg 1980;139:424-427.

24. REYES-GOVEA J, HOLM A \& ALDRETE JS - Response of glucagonomas to surgical excision and chemoterapy. Report of two cases and review of the literature. Am Surg 1989;35:523-527.

25. SMITH AP, DOOLAS A \& STAREN ED - Rapid resolution of necrolytic migratory erythema after glucagonoma resection. J Surg Oncol 1996;61:306-309.

26. ALTIMARI AF, BHOOPALAM N, O'DORSIO T et al. - Use of somatostatin analog (SMS 201-995) in the glucagonoma syndrome. Surgery 1986;100:989-996.

27.CH'ING JL, ANDERSON JV, WILLIANS SJ et al. - Remission of symptoms during long term treatment of metastatic pancreatic endocrine tumours with long acting somatostatin analogue. Br Med J 1986;292:981-982.

28. MARLISS EB, AOKI TT, ONGER RH et al. - Glucagon levels and metabolic effects in fasting man. J Clin Invest 1970;49:2256-2270.

29. NORTON JA, KAHN CR, SCHIEBINGER R et al. - Amino acid deficiency and the skin rash associated with glucagonoma. Ann Intern Med 1979;91:213-215.

30. SHEPHERD ME, RAIMER SS, TYRING SK et al. - Treatment of necrolytic migratory erythema in glucagonoma syndrome. J Am Acad Dermatol 1991;25:925-928. 
31. MARRI-FRIDLING GD \& TURNER MLC - Necrolytic migratory erythema without glucagonoma. J Am Acad Dermatol 1992;27:486.

32. DELANEY TJ \& UFF JS - Necrolytic migratory erythema: Apparent response to oral omega-3 ( marine ) essential fatty acids. Br J Dermatol 1990;123(suppl. 37):107-109.

33. SINCLAIR AS \& REYNOLDS N - Necrolytic migratory erythema and zinc deficiency. Br J Dermatol 1997;136:783-785.
34. MALLINSON CN, HANLEY J, ALLISON DJ et al. - Treatment of malignant pancreatic glucagonoma: effect of zinc on the rash an hepatic arterial embolization on liver metastases. Gut 1978;19:A448.

35. MILLER SJ - Nutritional deficiency and the skin. JAm Acad Dermatol 1989;21:1-30.

36. COHEN PR \& PRYSTOWSKY JH - Metabolic and nutritional desorders. In: SAMS JRWM \& LYNCH PJ - Principles and practice of dermatology. $2^{\text {nd }}$ ed. New York, Livingstone, 1996. c. 61, p.693-712.

Received for publication on November 24, 2000. 